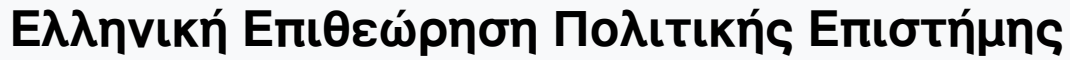

Tóp. 41 (2013)

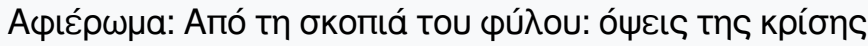

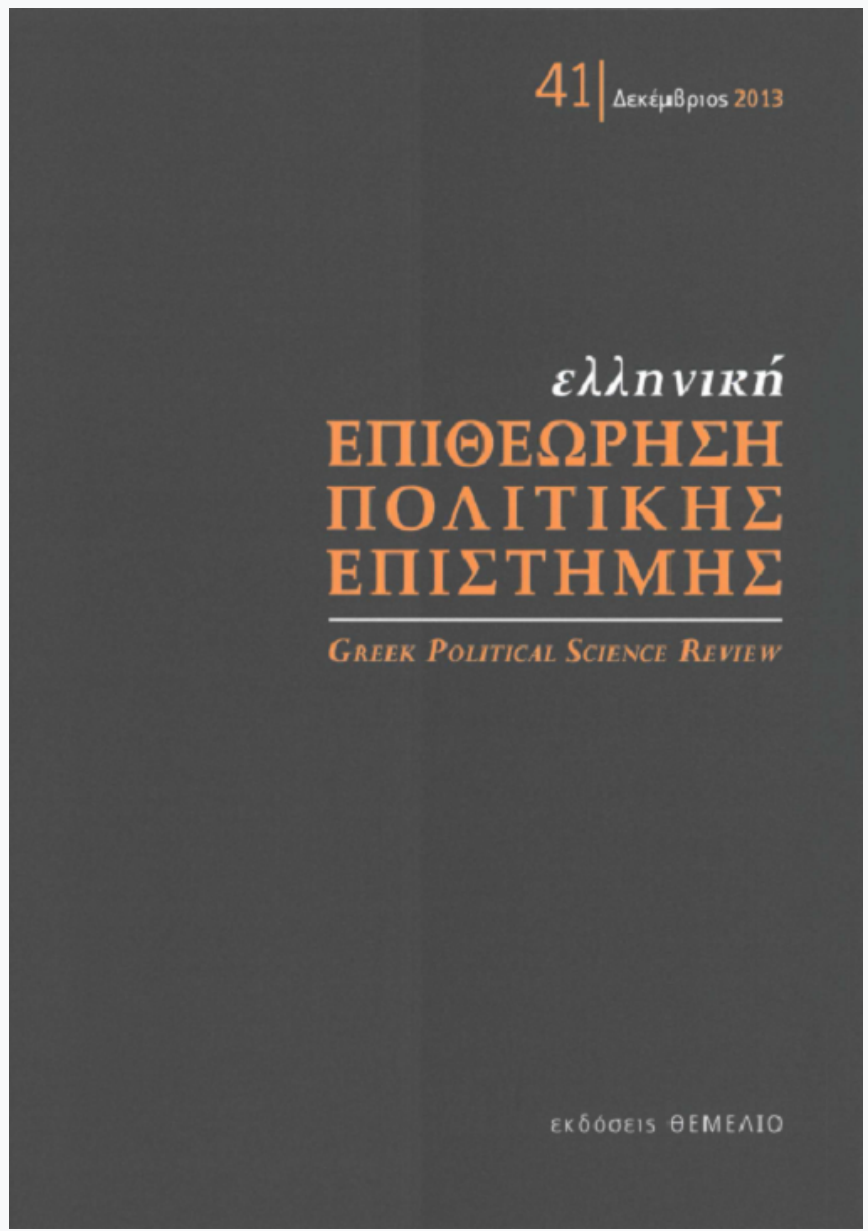

Today, more than ever: A comment on the so called "secondary" issues facing the Left in a period of crisis

Eléni Varikas

doi: $10.12681 /$ hpsa.14539

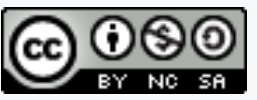

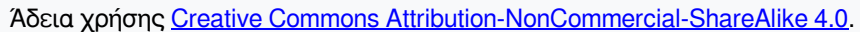

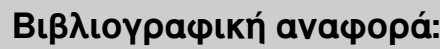

Varikas, E. (2017). Today, more than ever: A comment on the so called "secondary" issues facing the Left in a period of

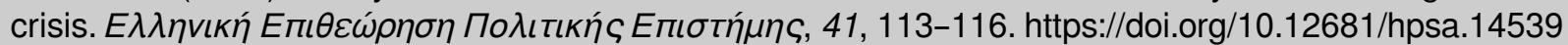




\title{
TODAY, MORE THAN EVER: \\ a COMMENT ON THE SO CALled "SECONDARY" ISSUES FACING THE LEFT IN A PERIOD OF CRISIS
}

\section{Eléni Varikas}

\begin{abstract}
"All fixed fast-frozen relations, with their train of ancient and venerable prejudices and opinions, are swept away, all new-formed ones become antiquated before they can ossify. All that is solid melts into the air, all that is holy is profaned, and man is at last compelled to face with sober eyes, his real conditions of life and his relations with its kind". Karl Marx, The Communist Manifesto
\end{abstract}

The optimistic undertones in which Marx alluded to the disenchantment of the world, were but a pale anticipation of the candid faith in the emancipating dynamics of modern secularised society, a faith which was to undermine the subversive potential and universalistic promises of socialist and other radical traditions for more than a century after the Communist Manifesto. The idea that, once delivered from the divine spell, human beings would be "compelled to face with sober sense", their "real conditions of life" no doubt expressed the unprecedented sense of liberty and hope enclosed in the liberating force of human action; but at the same time, it certainly underestimated the spell cast by the "new-formed relations".

Nowhere this spell has proved so strong as in the association of racism, anti-Semitism, sexism, and xenophobia to residual, backward mentalities, obscurantism prejudices, or uncompleted modernisation, association which assumed that these are destined to be wiped away with the progress and consolidation of a new secular or rational order. For though the development and

* Eléni Varikas is Professor Emerita. Université Paris 8, CRESPPA/CNRS. 
constant reformulation of such forms of discrimination and oppression have certainly drawn on, and reactivated, "traditional" earlier cultural patterns and mentalities, they are nevertheless inextricably connected to the new secular order of political legitimisation, its antinomies, its double dynamics.

Stressing common humanity as a sufficient ground for equality, secularized universalism, within the new political order, worked as a powerful impulse of what Ernst Bloch has called the "erect stride of humankind towards human dignity". Liberated from the theocratic hold of religion, natural right and common humanity provided, for the first time in such a large scale, legitimate ground for comparison of the social position of the oppressed to that of the dom inant orders, thus permitting to identify inequality with injustice.

It is, ironically, this novel fragility which political universalism introduced into the heart of the legitimation of inequality and domination that created the need for the dominant classes to turn difference into a source of anthropological inferiority. The connection established between physical, "racial" characteristics and political rights and duties, was a specifically modern political phenomenon. Its novelty resided first in that it resorted to Nature -the new indisputable ground for legitimating domination which had replaced the older metaphysical explanation of inequality. Inspired by the mathematical logic "Science is measurement", the concept of nature, inherent in the ideology of natural right, was employed to neutralise the "socialist" element within comparison, reducing what is qualitatively different into a set of quantifiable determinations.

Nature, viewed in the real or imaginary evidence of the colour of skin, of facial lines, of breasts, muscles and genital organs, could be thus used not just to contest human equality, but also, and this was a frightfully novel component in the history of domination, to break the unity of humankind. Indeed as long the faith in a divine order guaranteed social and political hierarchy, anthropological continuity between blacks and whites, Jews and Gentiles, men and women did not challenge social inequality and, consequently, the unity of humankind was not in danger. But as this unity became the fundamental source of human rights, inequality seemed arbitrary, unless it could be based on differences so radical that no common denominator was possible.

Naturalisation of social differences offered a privileged way out of the instability in legitimating domination. Inspired by the classifications of natural science, the idea of biological endowment re-elaborated the aristocratic notion of heritage in terms compatible with the new political system. It recon- 
ciled the fiction of free individuals with persisting social inequality, the abolition of birth privilege with the persistence of ascribed privileges. But most of all naturalisation of domination and oppression contributed to establish a specifically modern connection between power relations of diverse origins and character (racism, anti-Semitism, gender oppression, colonialism) by attaching their social acceptability to the same logic of legitimation: a logic which transformed equality from a bond between the constitutive differences of humankind into a principle incompatible with difference.

Modern constructions of otherness into source of inferiority, political incapacity and domination were not the immediate result of scientific knowledge. They stemmed from the need to provide watertight arguments for ideas produced as political weapons; yet, though they were produced in the realm of the new conflicting social relations whose legitimacy was unstable, they drew their authoritative power in the new sacralisation of Science and instrumental reason whose immediate outcome, scientism, was to infect not only dominant bourgeois ideologies, but also the critical understanding of power relations and the struggles against domination and oppression.

The Eurocentric "prejudices" which shaped the understanding of modern society and culture in Marxist and socialist traditions, the "opinions" which favoured the positivist and determinist conceptions of history and class-struggle or the social-Darwinist theories within the Second International, the "beliefs" which fostered the systematic gender and race discriminations within the left, are not just residues of traditional "fast-frozenrelations"; they are the expression of the social and political dynamics of the "new-formed" relations and of the lasting difficulty to resist them. Their development corresponded to, and was fostered by, the founding axiom of the modern State, the principle of one and indivisible power and the ensuing lasting suspicion it cast upon human diversity and multiplicity. The state practices of the two last centuries -including the welfare-state and "democratic" state (eugenics, family and protective legislation, immigration policies, racial segregation)- should suffice to remind us how much coercion and suffering it took for "difference" to be constructed as the antipodes of equality.

Our century has tragically exposed the illusion of progress by revealing mass-murder, the unprecedented crime against human plurality and, recently, the horror of ethnic purification, as possible, though not ineluctable, outcomes of political modernity. In failing to grasp the double dynamics of modernity -the dialectic of Enlightenment- the dominant traditions of the 
left have failed to "face soberly" existing reality and to resist it. Rather than bow to the crashing weight of this assessment, today, more than ever, we have to bear in mind that, as young Adorno wrote in the 1930s, the interpretation of given reality is bound up to its abolition.

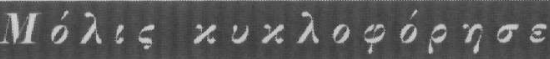

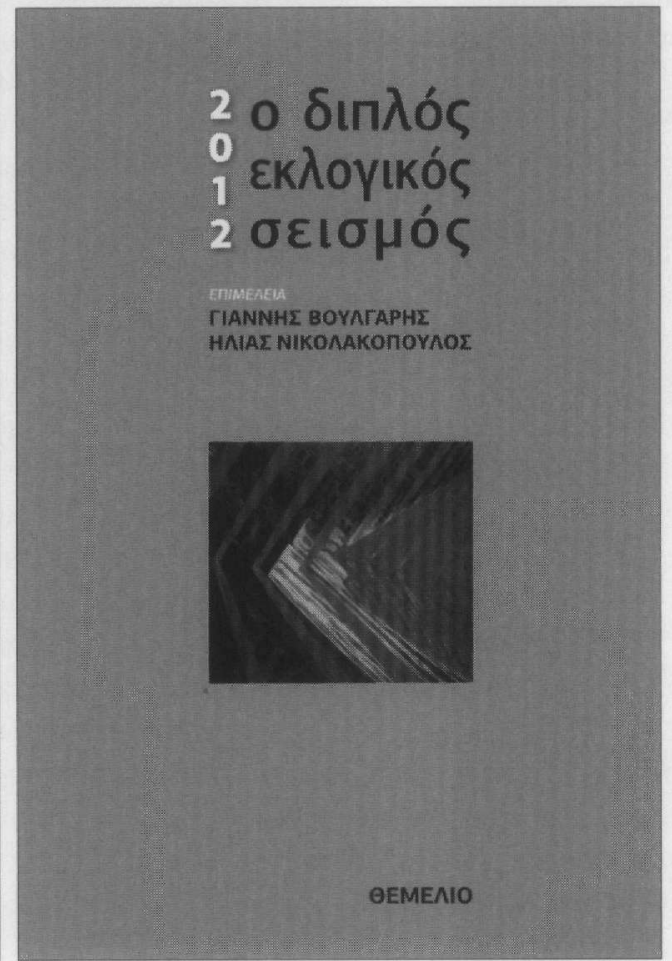

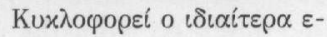
$\pi i x \alpha\llcorner\rho \circ \varsigma$ $\sigma v \lambda \lambda o \gamma \iota x o ́ s$ tó-

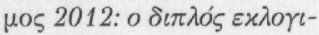

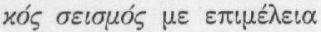

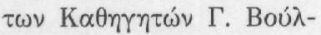

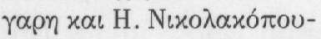

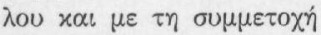

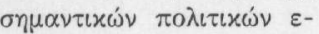
$\pi \iota \sigma \tau \eta \mu o ́ v \omega \nu . \quad ' E v \alpha \quad \beta \iota \beta \lambda i o$

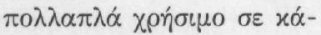

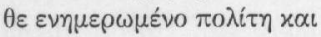

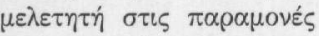

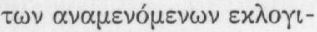
$\chi \omega \dot{\nu} \mu \varepsilon \tau \alpha \sigma \varepsilon\llcorner\sigma \mu \omega \dot{\nu .}$

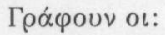

Г. BOҮ ГАРН

B. ГЕ РРГІААO

K. EAEY $\Theta E P I O Y$

П. KOT $2 T E N H \Sigma$

K. $\triangle A M \Pi P I N O Y$

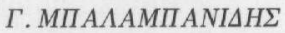

H. NIKОААКОПОКАОГ

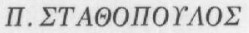

ER.TEПЕРОГАO

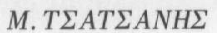

ISBN 978-960-310-371-4

\section{$\sigma=\dot{0} \lambda \alpha=\alpha 666 \lambda, 0 \pi \omega \lambda \varepsilon i \alpha$}

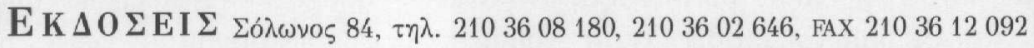
$\Theta$ E M E $\Lambda$ I 0 http://www.themelio-ekdoseis.gr, e-mail: info@themelio-ekdoseis.gr 